\title{
Gastrointestinal parasites occurrence in dairy cows kept in organic and conventional production system
}

\section{Ocorrência de parasitas gastrintestinais em vacas leiteiras mantidas em sistema orgânico e convencional}

\author{
Jenevaldo Barbosa da Silva ${ }^{1 *}$; João Paulo Guimarães Soares²; \\ Adivaldo Henrique da Fonseca ${ }^{3}$
}

\begin{abstract}
The main aim of this study was to determine the effects of pregnancy, calving, lactation, lactation number and seasons on the population of gastrointestinal helminths in dairy cows kept in organic and conventional production system. Between January 2007 and December 2009, coproparasitologic exams were performed using 72 and 43 cows kept in conventional and organic system, respectively. The data was submitted to analysis of variance and Student and Tukey test, both at $5 \%$ of significance level. There was no difference ( $p>0.05$ ) between faecal egg count $($ FEC) of organic and conventional animals. The mean FEC during calving and lactation was higher $(\mathrm{p}<0.05)$ than during pregnancy. There was no effect of season on the FEC in dairy cows kept in conventional system, while the dairy cows kept in organic system were significantly $(p<0$.05) more infected during the rainy season. In both production systems the primiparous animals showed FEC significantly higher $(\mathrm{p}<0.05)$ than pluriparous animals. Dairy cows kept in organic and conventional system were equally vulnerable to the subclinical helminthiasis, and the birth order was a risk factor in both systems.
\end{abstract}

Key words: Helminths, sustainable production, immune decrease

\section{Resumo}

O objetivo do estudo foi determinar os efeitos da gestação, parto, lactação, número de lactações e estação do ano sobre as populações de helmintos gastrintestinais em vacas leiteiras mantidas em sistema de manejo orgânico ou convencional. Entre janeiro de 2007 e dezembro de 2009 foram realizados exames coproparasitologicos de 72 vacas criadas em sistema convencional e 43 em sistema orgânico. Os dados foram submetidos a analise de variância e aos testes Student e Tukey a 5\% de significância. Não foi observada diferença $(p>0,05)$ entre a contagem de ovos nas fezes $(\mathrm{OPG})$ dos animais orgânicos e convencionais. A média do OPG durante o parto e lactação foi maior $(\mathrm{p}<0,05)$ do que na gestação. Não foi observada influência da estação do ano sobre o OPG nos animais criados no sistema convencional, no entanto os animais do sistema orgânico foram mais parasitados $(\mathrm{p}<0,05)$ durante o período chuvoso. Em ambos os sistemas de produção os animais primíparos apresentaram OPG maior $(\mathrm{p}<0,05)$ do que os animais pluríparos. Vacas de leite mantidas em sistema orgânico ou convencional foram igualmente vulneráveis a helmintoses subclínicas, sendo a ordem de parto um fator de risco nos dois sistemas.

Palavras-chave: Helmintos, produção sustentável, relaxamento imunológico

\footnotetext{
1 Discente de Doutorado da Faculdade de Ciências Agrárias e Veterinária, FCAV/UNESP, Jaboticabal, SP. E-mail: jenevaldo@, hotmail.com

2 Pesquisador da Empresa Brasileira de Pesquisa Agropecuária, EMBRAPA, Brasília, DF. E-mail: jp.soares@cpac.embrapa.br

3 Prof. da Universidade Federal Rural do Rio de Janeiro, UFRRJ, Seropédica, RJ. E-mail: adivaldofonseca@yahoo.com.br

* Author for correspondence 


\section{Introduction}

During the second half of the $20^{\text {th }}$ century and the beginning of the present, the world has experienced an accelerated modernization process with unsustainable long-term growth (HENRIOUD, 2011). Parasites of domestic ruminants directly or indirectly contribute to reduced sustainability affecting food security in subsistence or small scale farming systems, food safety, environment and farmer's equity (HENRIOUD, 2011).

The battle against helminths in tropical countries has been conducted mainly by the uncontrolled use of anthelmintic compounds (CRUZ et al., 2010). Although these drugs have been efficient, the absence of protocols adapted to tropical regions in addition to the inordinate use of therapeutic base has led to the increased cost of production. In addition, it contributes to the emergence of resistant strains and increasing contamination of water supplies and foodstuffs.

In organic production system, gastrointestinal nematodes are considered the biggest health problem, with important impact on the profitability of milk production (LARSSON et al., 2007). The regulations of the Law 10831, which characterizes the national organic agriculture (BRASIL, 2003) through the normative Instruction 64 (BRASIL, 2009), prohibits the use of prophylactic anthelmintic, being only allowed the treatment of animals with herbal medicines, herbal extracts and homeopathic. Thus, for the rational and sustainable control of helminths, it is necessary to understand the epidemiology of the parasites, pasture management, sanitary control of the environment and animals (LARSEN, 2002).

In herds, the peripartum cows are considered the main responsible for the contamination of pastures and subsequent infection of susceptible animals (BARGER, 1993). Studies have shown that during late pregnancy and early lactation there is reduction of the systemic antibody levels (JEFFCOATE et al., 1990) and reduction of cellular immune response
(HUNTLEY et al., 2004). Some factors have been identified as modulators of immune response during the peripartum period as metabolism of proteins (DONALDSON; VAN HOUTERT.; SYKES, 2001), genetics of host (BARGER, 1993) and hormones such as prolactin (GIBBS, 1967).

During peripartum there is the "immune relaxation" phenomenon in which the animals are most susceptible, making them vulnerable to parasites (JANSEN, 1982). Thus, the study aimed to assess the effects of pregnancy, parturition, lactation, seasons and birth order on the populations of gastrointestinal helminths in dairy cows kept in organic and conventional production system.

\section{Materials and Methods}

Field activities were conducted from January 2007 to December 2009, at the Dairy Cattle Division of Seropédica Experimental Station, Empresa de Pesquisa Agropecuária do Estado do Rio de Janeiro (Pesagro-Rio; Agricultural and Livestock Research Corporation of the State of Rio de Janeiro). The experimental area was located in the metropolitan microregion of the city of Rio de Janeiro (latitude $22^{\circ} 45^{\prime} \mathrm{S}$, longitude $43^{\circ} 41^{\prime} \mathrm{W}$ and altitude 33 meters).

In the first study, 72 cows with breed standard from $3 / 8$ Gir $x 5 / 8$ Holstein to $5 / 8$ Gir x $3 / 8$ Holstein were analyzed. The animals were kept in conventional production system. Among the animals, 35 calved during the rainy season (October-March) and 37 during the dry season (April-September). Regarding parturition, 20 animals were at their $1^{\text {st }}$ lactation, 22 animals were at their $2^{\text {nd }}$ lactation and 30 animals were at their $3^{\text {rd }}$ or subsequent lactation. In the second study, 43 cows were analyzed with the breed standard of the cows was $3 / 4$ Gir x $1 / 4$ Holstein. These animals were kept in organic production system. Among these animals 20 gave birth during the rainy season and 23 during the dry season. There were 11 animals at their $1^{\text {st }}$ lactation, 12 animals at their $2^{\text {nd }}$ lactation and 20 animals at their $3^{\text {rd }}$ or subsequent lactation. 
In the conventional system, the pregnant cows were kept on an area of Brachiaria decumbens at an animal density of three cows per hectare for the 30 days prior to calving. After calving and during the first four weeks of lactation, the animals were kept on pasture consisting of $B$. decumbens and Panicum maximum at a density of three animals per hectare. In both areas, the animals received water and mineral salt ad libitum. During the lactation period, the cows were milked twice a day. The cows received $3 \mathrm{~kg}$ of commercial concentrate consisting of citrus pulp and commercial ration with $22 \%$ crude protein, in the proportions of $2: 1$, per day. During the experimental period animals were treated, four times a year, with ivermectin $(0.2 \mathrm{mg} / \mathrm{kg})$.

In the organic system, the pasture was divided in 7 paddocks, grazed during 7 days with 42 days of rest period and stocking rate of 2 cows/ha. During the rainy season, the cows were kept in Tanzania pasture (Panicum maximum cv. Tanzania) mixed with Calopo (Calopogonium muconoides) and received $2 \mathrm{~kg} / \mathrm{cow} /$ day of concentrate $(18 \% \mathrm{CP})$. In the dry season the animals were supplemented with elephantgrass (Pennisetum purpureum Schum cv cameroom) mixed with Siratro (Macropitilium atropurpureum). In this system cows did not receive athelmintic treatment.

Feces from the cows were sampled three times per week: during the four weeks of the prepartum period, in the week of calving and in the four weeks of the postpartum period. The fecal parasitological analyses were performed at the Parasitic Diseases Laboratory, Department of Epidemiology and Public Health, Institute of Veterinary Medicine of the Federal Rural University of Rio de Janeiro. The faecal eggs count (FEC) of gastrointestinal nematodes in the feces was accomplished through the technique described by Ueno and Gonçalves (1998).

For statistical analysis the data on the mean FEC were initially transformed into $\log _{10}(x+1)$ in order to normalize them. In the quantitative assessment of different parameters, analysis of variance (ANOVA) was used, along with the Tukey and Student $\mathrm{t}$ tests at 5\% significance and linear regression. The operating procedures were performed using the statistical software Epi Info ${ }^{\circledR}$ version 3.5 (Centers for Disease Control and Prevention, Brazil, 2008).

\section{Results and discussion}

Throughout the study, the animals presented faecal egg counts ranging from mild to moderate. There was no significant difference $(p>0.05)$ between the egg counts in animals kept in organic and conventional systems (Table 1). Between periods, parasitism in parturition and lactation was significantly higher $(\mathrm{p}<0.05)$ than during pregnancy, being the faecal egg count during parturition and lactation did not differ significantly ( $\mathrm{p}>0.05)$.

Table 1. Mean values and standard deviations of eggs counts in feces of organic and conventional dairy cows, during pregnancy, calving and lactation, 2008-2009, Brazil.

\begin{tabular}{lccc}
\hline \multicolumn{1}{c}{ Production System } & Gestation & Calving & Lactation \\
\hline Organic & $235 \pm 25.2^{\mathrm{Ab}}$ & $525 \pm 70,8^{\mathrm{Aa}}$ & $535 \pm 95,7^{\mathrm{Aa}}$ \\
Conventional & $100 \pm 20,8^{\mathrm{Ab}}$ & $350 \pm 74,8^{\mathrm{Aa}}$ & $335 \pm 92,6^{\mathrm{Aa}}$ \\
Average & 217,5 & 648,5 & 530 \\
\hline
\end{tabular}

Averages followed by different uppercase letters in the columns and lowercase letters in the rows were statistically different according to the Tukey tests at $5 \%$ probability level, respectively.

Source: Elaboration of the authors. 
The moderate helminthes eggs count in organic animals, even without the use of traditional anthelmintic, can be attributed to management practices. The maintenance of cows in decontaminated pasture, combined with roughage supplementation during the dry season probably increased the resistance of organic animals, helping to reduce helminth infections, as well as the breed standard ( $3 / 4$ Gir $x$ 1/4 Holstein) given to these animals by crossing the bigger resistance to helminths diseases.

In Brazil, although the system of pasture management is used as a quick and simple solution for controlling nematodes, there is no control study of nematodes in grazing systems without the use of anthelmintics (BIANCHIN et al., 2007). According to Catto et al. (2009), although it has been recommended by producers and technicians related to organic farming, there are no experimental results or case studies that have shown its effect in controlling gastrointestinal nematodes of cattle in Brazil.

The high parasite load observed in adult animals, during parturition and lactation was due to the effect of peripartum immunological relaxation. Taylor (1935) was one of the first researchers to observe the influence of the peripartum in the Trichostrongylides egg count, having found that the egg counts were low in winter, had increased in the spring and then declined again in winter. However, this author noted that this variation did not indicated relation with the increase or reduction of infective larvae on pastures, and yes, the variation in the speed of egg production by helminths.

In this study, the highest average count of eggs in the parturition and lactation in comparison to pregnancy stresses theimportance of thephenomenon of peripartum immunological relaxation on the size of the population of gastrointestinal helminths (CONNAN, 1968). According to Mirkena et al.
(2010), gastrointestinal nematodes are a problem not only for calves, but also for breeding females, especially during late pregnancy and early lactation. During this period the animals are immunologically susceptible. These authors demonstrated that the postpartum stage may be the most appropriate one to evaluate the resistance of animals of different genetic patterns to gastrointestinal helminths.

In early lactation, there was an increase in nutritional needs which the dairy cow was unable to meet only with the intake of dry food. Then the cows started the mobilization of body reserves. The immune system is responsible for a large nutritional support, there is consequently a reduced immune response. When the metabolic burden reaches a level where it becomes difficult, the animal will no longer be able to cope with possible pathogens (HELMBY, 2009).

In the organic system there was a statistical difference $(p<0.05)$ between parasite load of animals that calved during the rainy and dry season, but in the conventional system was not significant difference $(p>0.05)$ between seasons (Figure 1). In organic animals during the rainy season, it was found that the FEC during parturition was statistically superior $(p<0.05)$ than during lactation. However, this difference was not observed during the dry season.

During the rainy season it was observed significant increase $(p<0.05)$ in the eggs count after parturition, a fact that was not observed among the animals that calved in the dry season. Donaldson, Van Houtert and SYKES (2001) observed that cows in late pregnancy and early lactation have a high protein demand. This increased nutritional requirement during parturition is due to the production of antibodies from colostrum, milk proteins, beyond the necessity that the cow has to restore its immune system, because a lot of their antibodies passively passed into breast milk and need to be synthesized again. 
Figure 1. Egg counts in feces from cows during the prepartum, calving and postpartum periods, in the rainy and dry seasons, 2008-2009, Brazil.
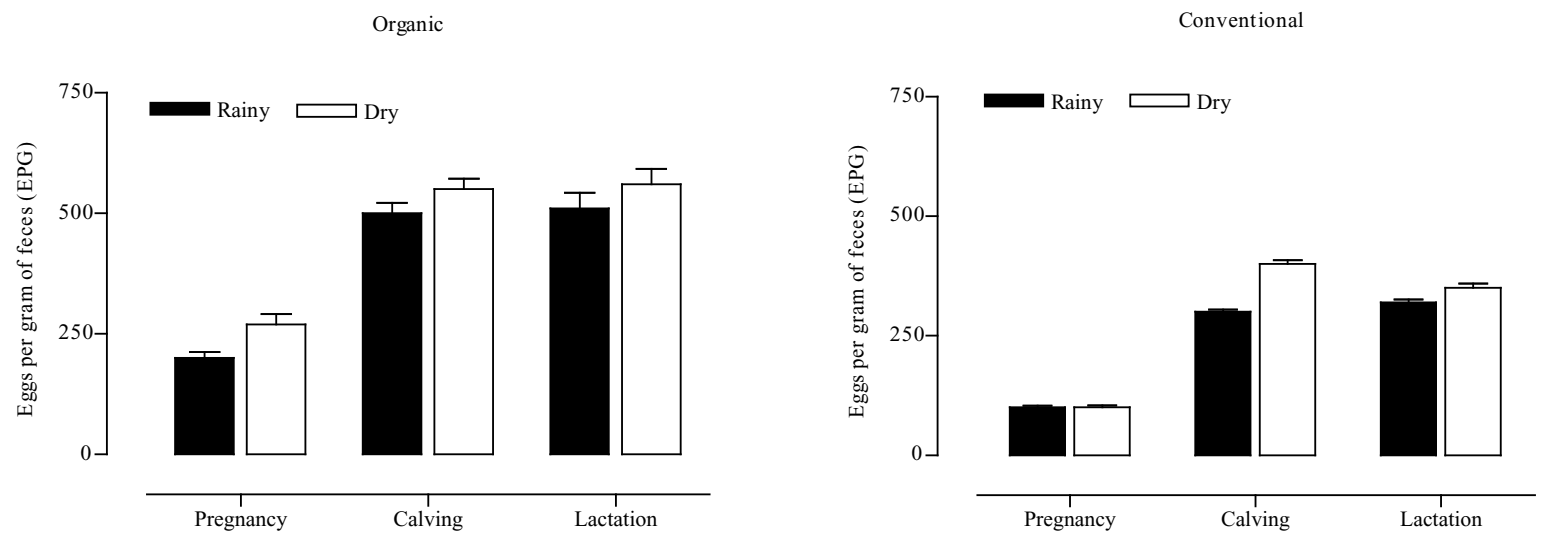

Source: Elaboration of the authors.

In this study, the highest FEC during spring and summer occurred possibly due to the increased availability of larvae on pasture. In studies on the seasonal fluctuation of gastrointestinal nematodes in dairy cows kept in organic system (SILVA; SOARES; FONSECA, 2012a) and dairy cows kept in conventional system (SILVA et al., 2012b), the peripartum phenomenon contributed significantly towards increased FEC, thus overcoming the risk factor of season.
Significant difference $(p<0.05)$ were found between parasite load of primiparous and multiparous cows in organic and conventional system as shown in Figure 2. The elimination of eggs in the feces varied significantly $(p<0.05)$ depending on the number of lactation, and during pregnancy, parturition and lactation, primiparous cows had higher FEC compared to multiparous cows. There was no statistical difference $(\mathrm{p}>0.05)$ between the FEC in animals $2^{\text {nd }}, 3^{\text {rd }}$ or more lactation.

Figure 2. Egg counts in feces from cows at the first, second and third or subsequent lactation, during the prepartum, calving and postpartum periods, 2008-2009, Brazil.
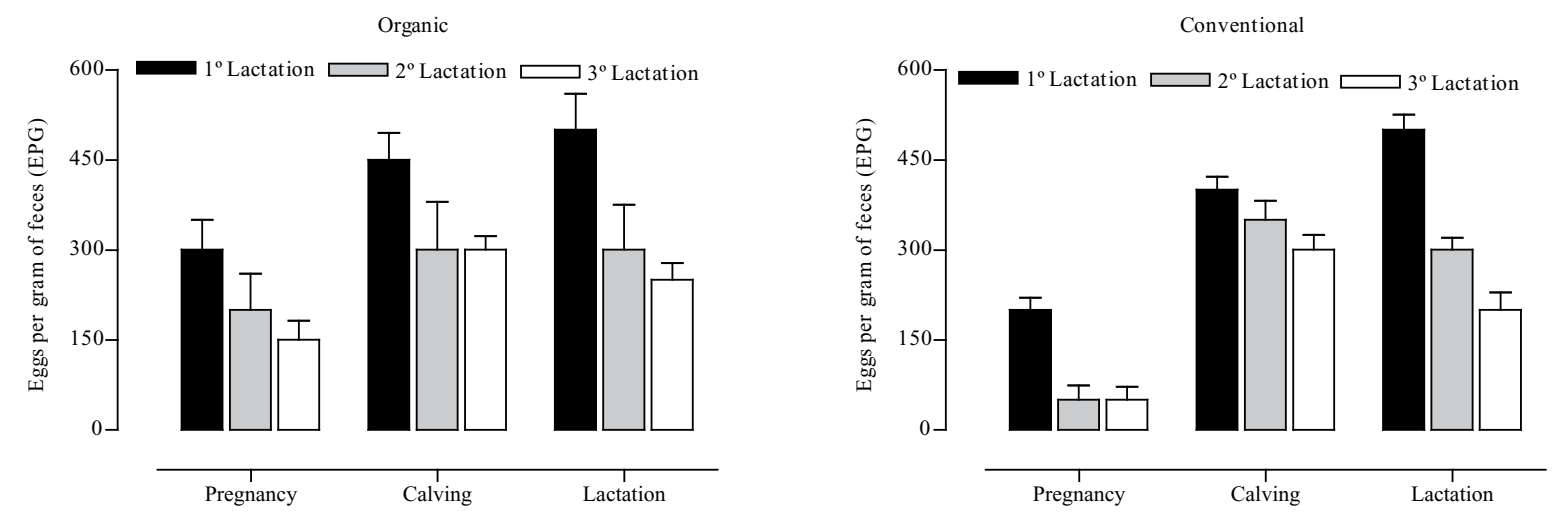

Source: Elaboration of the authors. 
Gennari et al. (2002) observed that a high level of nematode egg elimination occurred during the peripartum period in Holstein dairy cows. These authors observed that animals at their $3^{\text {rd }}$ or subsequent lactation were more resistant, resulting in the declining of the values of eggs in feces. Silva et al. (2012b) observed that many factors can affect the egg count during calving; among them it is important to mention lactation.

Silva et al. (2012b) studied the influence of physiological factors in parasite load. It was observed that females of the first lactation are more susceptible to helminthiasis than multiparous females. The results showed that first lactation cows had a higher abundance of gastrointestinal parasites, proving that the order of calving is a risk factor for the development of helminthes infections. Previous studies suggest the hypothesis that the greater receptiveness to helminths of cows at their first lactation is due to the lack or low intensity of previous contacts with helminths and the absence of an immune response capable of regulating the populations of worms (SILVA et al. 2012b).

The current results confirm that the cows at their first lactation should represent the specific target of surveillance and possible selective treatment in this group of animals at most risk of the herd. Such selective treatment would be of great interest to slow the spread of anthelmintic resistance (GENNARI et al., 2002) in addition to reducing production costs with chemotherapy.

The results from coprological cultures demonstrated that Haemonchus was predominant (66\%), followed by Trichostrongylus (26\%), Cooperia (6\%) and Oesophagostomum (2\%). There was no significant difference $(\mathrm{p}<0.05)$ between the helminth populations in the two groups. During the peripartum, there was no statistical difference $(p>0.05)$ in terms of the composition of the populations of gastrointestinal parasites. The comparison between the seasons demonstrated that, in the dry season, the quantity of Haemonchus larvae decreased significantly $(\mathrm{p}>0.05)$, relative to Trichostrongylus.
The predominance of Haemonchus is worrisome given that this infection can cause severe anemia and hypoproteinemia and depression, loss of body condition, reduced productivity and possibly death (KAPLAN et al., 2004). Perry et al. (2002) affirmed that Haemonchus contortus was singly the most important of all the gastrointestinal nematodes that constrain the survival and productivity of goats owned by the rural poor in the developing world. This haematophagous parasite is infamous throughout the humid tropics/subtropics, being responsible for acute disease outbreaks with high level of mortalities, particularly in young animals (KRECEK; WALLER, 2006).

Although the aim of this study was not evaluate productive and reproductive parameters, some observations are worth mentioning. In the conventional system there was a miscarriage rate of $4.16 \%(3 / 72)$ whereas in organic system no abortion was diagnosed $2.3 \%(1 / 43)$. The mortality rate at weaning in the conventional system was $2.7 \%$ $(2 / 72)$ and in the organic system was $4.6 \%(2 / 43)$. The number of twin pregnancies, birth weight and weaning did not differ significantly $(\mathrm{p}<0.05)$ between the two production systems. These results demonstrated that the organic system besides being environmentally friendly is also economically viable.

Sustainable parasite control is not an absolute concept given the different regions and productive systems of the world. Indeed the objectives and technological possibilities to implement sustainable practices for commercial farming systems in France or USA are not the same for a resource-poor livestock producer under subsistence farming systems in a remote Andean area in South America or in sub-Saharan Africa. Therefore, it is necessary to have a conceptual framework to better understand how far is each region or country from applying rational practices of parasite control while increasing animal production in a sustainable way (HENRIOUD, 2011).

Animals kept on organic and conventional system proved to be equally vulnerable to 
subclinical helminthiasis. The highest risk group of gastrointestinal parasites in organic and conventional system was the primiparous cows that calved during the rainy season, especially during their calving and lactation.

\section{Acknowledgments}

To the National Council for Scientific and Technological Development (CNPq), and to the Coordination for Improvement of Higher Education Staff (CAPES) for the financial support.

\section{References}

BARGER, J. A. Influence of sex and reproductive status on susceptibility of ruminants to nematode parasitism. International Journal Parasitology, New York, v. 33, n. 4, p. 463-469, 1993.

BIANCHIN, I.; CATTO, J. B.; KICHEL, A. N.; TORRES JÚNIOR, R. A. A.; HONER, M. R. The effect of the control of endo and ectoparasites on the weight gains in crossbred cattle (Bos taurus x Bos indicus) in the central region of Brazil. Tropical Animal Health and Production, Midlothian, v. 39, n. 4, p. 287-296, 2007.

BRASIL. Lei n. ${ }^{\circ}$ 10831, de 23 de dezembro de 2003. Dispõe sobre a agricultura orgânica e dá outras providências. Diário Oficial [da] República Federativa do Brasil. Brasília DF, 23 dez. 2003. Disponível em: <http:// www.planalto.gov.br/ccivil_03/leis/2003L10.831.htm>. Acesso em: 12 dez. 2010.

Ministério da Agricultura, Pecuária e Abastecimento. Legislação para os sistemas orgânicos de produção animal e vegetal/Ministério da Agricultura, Pecuária e Abastecimento. Secretaria de Desenvolvimento Agropecuário e Cooperativismo. Brasília: MAPA/ACS, 2009. 195 p.

CATTO, J. B.; BIANCHIN, I.; SANTURIO, J. M.; FEIJÓ, G. L. D.; KICHEL, A. N.; SILVA, J. M. Sistema de pastejo, rotenona e controle de parasitas: Efeito sobre o ganho de peso e níveis de parasitismo em bovinos cruzados. Revista Brasileira de Parasitologia Veterinária, Jaboticabal, v. 18, n. 4, p. 37-43, 2009.

CONNAN, R. M. Studies on the worm populations in the alimentary tract of breeding ewes. Journal of helminthology, London, v. 42, n. 1-2, p. 9-28, 1968.
CRUZ, D. G.; ROCHA, L. O.; ARRUDA, S. S.; PALIERAQUIA, J. G. B.; CORDEIROA, R. C.; JUNIOR, E. S.; MOLENTO, M. B.; SANTOS, C. P. Anthelmintic efficacy and management practices in sheep farms from the state of Rio de Janeiro, Brazil. Veterinary Parasitology, Amsterdam, v. 170, n. 3-4, p. 340-343, 2010.

DONALDSON, J.; VAN HOUTERT, M. F. J.; SYKES, A. R. The effect of dietary fish-meal supplementation on parasite burdens of periparturient sheep. Animal science, Midlothian, v. 72, n. 1, p. 149-158, 2001.

GENNARI, S. M.; BLASQUES, L. S.; RODRIGUES, A. A.; CILENTO, M. C.; SOUZA, S. L.; FERREIRA, F. Determinação da contagem de ovos de nematódeos no período peri-parto em vacas. Brazilian Journal of Veterinary Research and Animal Science, Belo Horizonte, v. 39, n. 1, p. 32-37, 2002.

GIBBS, H. C. Some factors involved in the "Spring Rise" phenomenon in sheep. In: SOULSBY, E. J. L. (Ed.). The reaction of the host to parasitism. Marburg, Lahn: N.G. Elwert Universitats und Verlagsbuchand, 1967. p. 160-173.

HELMBY, H. Helminths and our immune system: Friend or foe? Parasitology International, New York, v. 58, n. 2, p. 121-127, 2009.

HENRIOUD, A. N. Towards sustainable parasite control practices in livestock production with emphasis in Latin America. Veterinary Parasitology, Amsterdam, v. 180, n. 2, p. 2-11, 2011.

HUNTLEY, J. F.; JACKSON, F.; COOP, R. L.; MACALDOWIE, C.; HOUDIJK, J. G. M.; FAMILTO, A. S.; XIEH, H. L.; STANKIEWICZ, M.; SYKES, A. $\mathrm{R}$. The sequential analysis of local inflammatory cells during abomasal nematode infection in periparturient sheep. Veterinary Immunology and Immunopathology, Amherst, v. 97, n. 2, p. 163-176, 2004.

JANSEN, J. Waarnemingen over de "spring rise" van strongylus type eieren bij de geit. Tijdschr Diergeneeskd, Amsterdam, v. 107, n. 2-3, p. 186-189, 1982.

JEFFCOATE, I. A.; WEDRYCHOWICZ, H.; FISHWICK, G.; DUNLOP, E. M.; DUNCAN, J. L.; HOLMES, P. H. Pathophysiology of the periparturient egg rise in sheep: the role of prolactin. Research in Veterinary Science, Roma, v. 48, n. 3, p. 295-300, 1990.

KAPLAN, R. M.; BURKE, J. M.; TERRILL, T. H.; MILLER, J. E.; GETZ, W. R.; MOBINI, S.; VALENCIA, E.; WILLIAMS, M. J.; WILLIAMSOM, L. H.; LARSEN, M.; VATTA, A. F. Validation of the FAMACHA eye color chart for detecting clinical anemia in sheep and 
goats on farms in the southern United States. Veterinary Parasitology, Amsterdam, v. 123, n. 1-2, p. 105-120, 2004.

KRECEK, R. C.; WALLER, P. J. Towards the implementation of the "basket of options" approach to helminth parasite control of livestock: emphasis on the tropics/subtropics. Veterinary Parasitology, Amsterdam, v. 139, n. 2-3, p. 270-282, 2006.

LARSEN, M. Biological control in a global perspective - a review with emphasis on Duddingtonia flagrans. In: BIOLOGICAL CONTROL OF NEMATODE PARASITES OF SMALL RUMINANTS IN ASIA, 2002, Rome. Proceedings... Rome, Italy: FAO, 2002. p. 104. (FAO Animal Production and Health Paper).

LARSSON, A.; DIMANDER, S. O.; WALLER, A.; UGGLA, A.; HÖGLUND, J. A 3- year field evaluation of pasture rotation and supplementary feeding to control parasite infection in first-season grazing cattle dynamics of pasture infectivity. Veterinary Parasitology, Amsterdam, v. 145, n. 3, p. 129-137, 2007.

MIRKENA, T.; DUGUMA, G.; HAILE, A.; TIBBO, M.; OKEYO, A. M.; WURZINGER, M.; SÖLKNER, J. Genetics of adaptation in domestic farm animals: A review. Livestock Science, Maryland Heights, v. 132, n. 1-3, p. 1-12, 2010.
PERRY, B. D.; MCDERMOTT, J. J.; RANDOLPH, T. F.; SONES, K. R.; THORNTON, P. K. investing in animal health research to alleviate poverty. Nairobi, Kenya: International Livestock Research Institute, 2002.

SILVA, J. B.; RANGEL, C. P.; BAÊTA, B. A.; FONSECA, A. H. Risk factors relating to helminth infections in cows during the peripartum. Revista Brasileira de Parasitologia Veterinária, Jaboticabal, v. 21, n. 2, p. 92-96, 2012 b.

SILVA, J. B.; SOARES, J. P. G.; FONSECA, A. H. Avaliação da carga parasitária de helmintos e protozoários em bezerros manejados em sistema orgânico. Semina: Ciências Agrárias, Londrina, v. 33, n. 3, p. 1103-1112, 2012a.

TAYLOR, E. L. Seasonal fluctuation in the number of eggs of trichostrongylid worms in the faeces of ewes. Journal of Parasitology, Richmond, v. 21, n. 3, p. 175179, 1935.

UENO, H.; GONÇALVES, P. C. Manual para diagnóstico das helmintoses de ruminantes. 4. ed. Tokyo: Japan International Cooperation Agency, 1998. 43 p. 